in vivo $35: 81-93(2021)$

doi:10.21873/invivo.12235

Review

\title{
Inflammatory Fibroid Polyp of the Gastrointestinal Tract: A Systematic Review for a Benign Tumor
}

\author{
NIKOLAOS GARMPIS ${ }^{1 *}$, CHRISTOS DAMASKOS ${ }^{2,3 *}$, ANNA GARMPI $^{4 *}$, VASILIKI E. GEORGAKOPOULOU ${ }^{5,6}$, \\ STRATIGOULA SAKELLARIOU $^{7}$, ALIKI LIAKEA ${ }^{7}$, DIMITRIOS SCHIZAS ${ }^{8}$, EVANGELOS DIAMANTIS $^{9}$, \\ PARASKEVI FARMAKI ${ }^{10}$, ERRIKA VOUTYRITSA ${ }^{3}$, ATHANASIOS SYLLAIOS $^{8}$, ALEXANDROS PATSOURAS $^{11}$, \\ GEORGIA SYPSA $^{12}$, ALEXANDRA AGOROGIANNI ${ }^{13}$, ATHANASIA STELIANIDI ${ }^{10}$, \\ EFSTATHIOS A. ANTONIOU ${ }^{1,3}$, KONSTANTINOS KONTZOGLOU ${ }^{1,3}$, \\ NIKOLAOS TRAKAS ${ }^{14}$ and DIMITRIOS DIMITROULIS ${ }^{1}$ \\ ${ }^{1}$ Second Department of Propedeutic Surgery, Laiko General Hospital, Medical School, \\ National and Kapodistrian University of Athens, Athens, Greece; \\ ${ }^{2}$ Renal Transplantation Unit, Laiko General Hospital, Athens, Greece; \\ ${ }^{3}$ N.S. Christeas Laboratory of Experimental Surgery and Surgical Research, Medical School, \\ National and Kapodistrian University of Athens, Athens, Greece; \\ ${ }^{4}$ First Department of Propedeutic Internal Medicine, Laiko General Hospital, Medical School, \\ National and Kapodistrian University of Athens, Athens, Greece; \\ ${ }^{5}$ Department of Pulmonology, Laiko General Hospital, Athens, Greece; \\ ${ }^{6}$ First Department of Pulmonology, Sismanogleio Hospital, Athens, Greece; \\ ${ }^{7}$ First Department of Pathology, Medical School, National and Kapodistrian University of Athens, Athens, Greece; \\ ${ }^{8}$ First Department of Surgery, Laiko General Hospital, Medical School, \\ National and Kapodistrian University of Athens, Athens, Greece; \\ ${ }^{9}$ Department of Endocrinology and Diabetes Center, G. Gennimatas General Hospital, Athens, Greece; \\ ${ }^{10}$ First Department of Pediatrics, Agia Sofia Children's Hospital, Medical School, \\ National and Kapodistrian University of Athens, Athens, Greece; \\ ${ }^{11}$ Second Department of Internal Medicine, Tzanio General Hospital, Piraeus, Greece; \\ ${ }^{12}$ Department of Pulmonology, Laiko General Hospital, Athens, Greece; \\ ${ }^{13}$ NHS Foundation Trust, Cambridge University Hospital, Cambridge, U.K.; \\ ${ }^{14}$ Department of Biochemistry, Sismanogleio Hospital, Athens, Greece
}

\begin{abstract}
Background/Aim: Inflammatory fibroid polyp (IFP) is a rare, usually solitary and intraluminal polypoid benign tumor that can affect any part of the gastrointestinal (GI) tract, although in the majority of cases it affects the

*These Authors contributed equally to this study.

Correspondence to: Dr. Christos Damaskos, MD, MSc, Ph.D., Renal Transplantation Unit, Laiko General Hospital, N.S. Christeas Laboratory of Experimental Surgery and Surgical Research, Medical School, National and Kapodistrian University of Athens; 17 Agiou Thoma Street, Athens 11527, Greece. Tel: +30 6948467790,e-mail: x_damaskos@yahoo.gr
\end{abstract}

Key Words: Inflammatory, fibroid, polyp, vanek, tumor, gastrointestinal, systematic, review. stomach. This lesion is characterized by proliferation of highly vascular fibrous tissue and infiltration by a variable number of different inflammatory cells. Its etiology is unknown. Our aim was to describe all the reported data concerning IFP. Materials and Methods: An extensive search of the PubMed Index was performed for publications with titles or abstracts containing the terms: "inflammatory fibroid polyp" with/without "Vanek". Results were filtered for publications in English and concerning only humans. One hundred and twenty-four publications were finally included in this review. Results: IFP has a female predominance. It affects patients in their 5th decade of life, although there are cases of patients from 4 to 84 years of age. IFP usually affects the stomach and more specifically the gastric antrum but can be detected throughout the GI tract. A significant number of cases remain asymptomatic but 


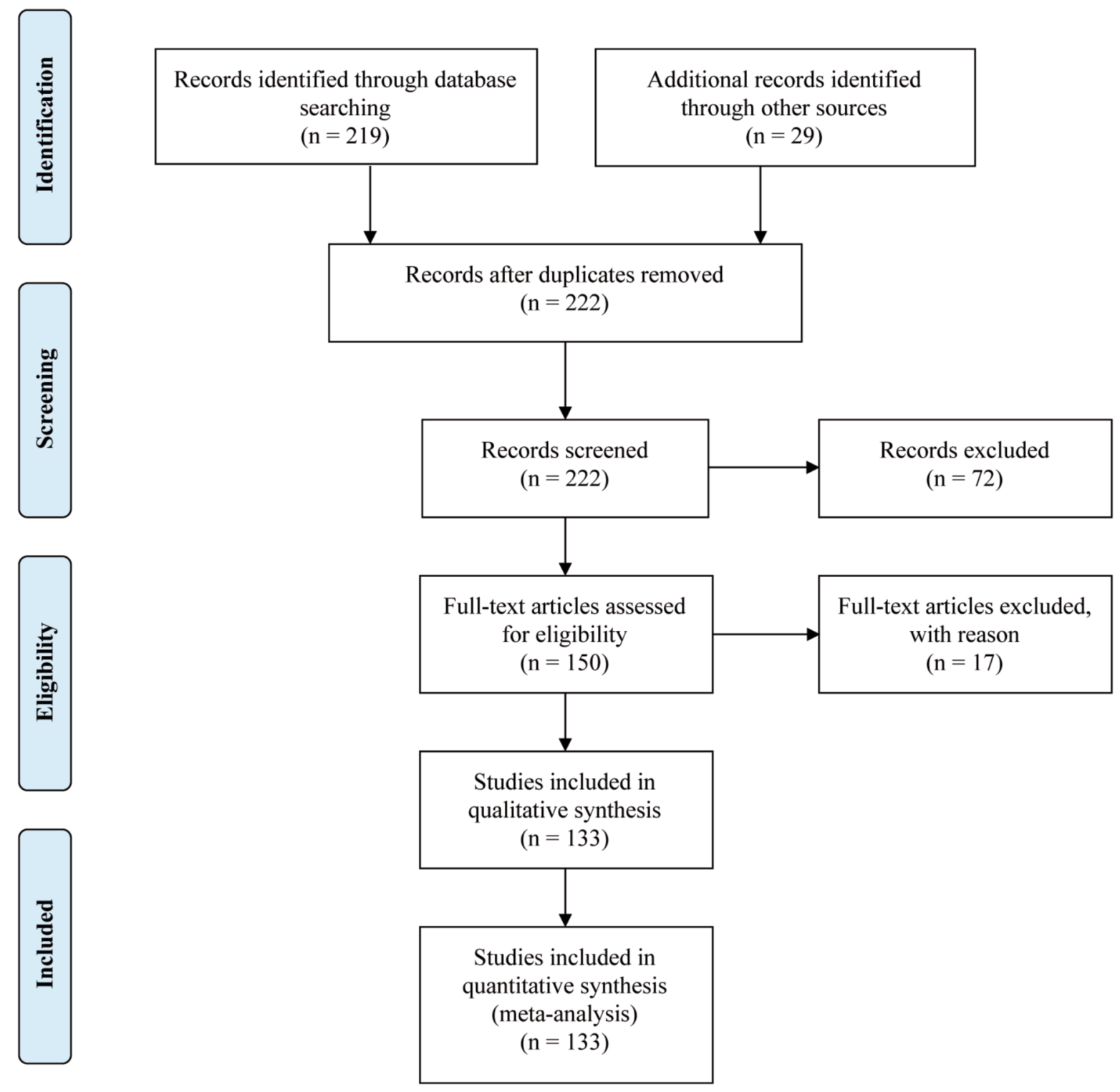

Figure 1. PRISMA flow for the current literature review.

the most frequent presentations of IFP are abdominal pain, acute abdomen and GI bleeding. Most cases are treated by endoscopic resection of the lesion. No recurrence nor IFPspecific complications have been reported. Histopathology of IFP varies. Conclusion: It is relatively safe to conclude that both the etiology and the timing of diagnosis might change the histopathology, immunohistological staining and tissue structure of IFP. Suggested theories should be taken into consideration with caution as the etiology and pathophysiological mechanisms of IFP are unknown.

Inflammatory fibroid polyp (IFP) was first described by Vanek in 1949 as a 'submucosal granuloma with eosinophilic infiltration' (1). IFP is a rare, usually solitary and intraluminal polypoid benign tumor that can affect any part of the gastrointestinal (GI) tract, although in the majority of cases it affects the stomach. This lesion is characterized by proliferation of highly vascular fibrous tissue and infiltration by a variable number of different inflammatory cells. The term IFP has gained wide acceptance since its first use in a 1953 publication by Helwig and Ranier (2). A plethora of different names have been suggested to describe IFP, such as eosinophilic granuloma, granuloblastoma or gastric fibroma with eosinophilic infiltration, granuloma with eosinophils, hemangiopericytoma, inflammatory fibroid tumor, and inflammatory pseudotumor $(3,4)$. The great number of 

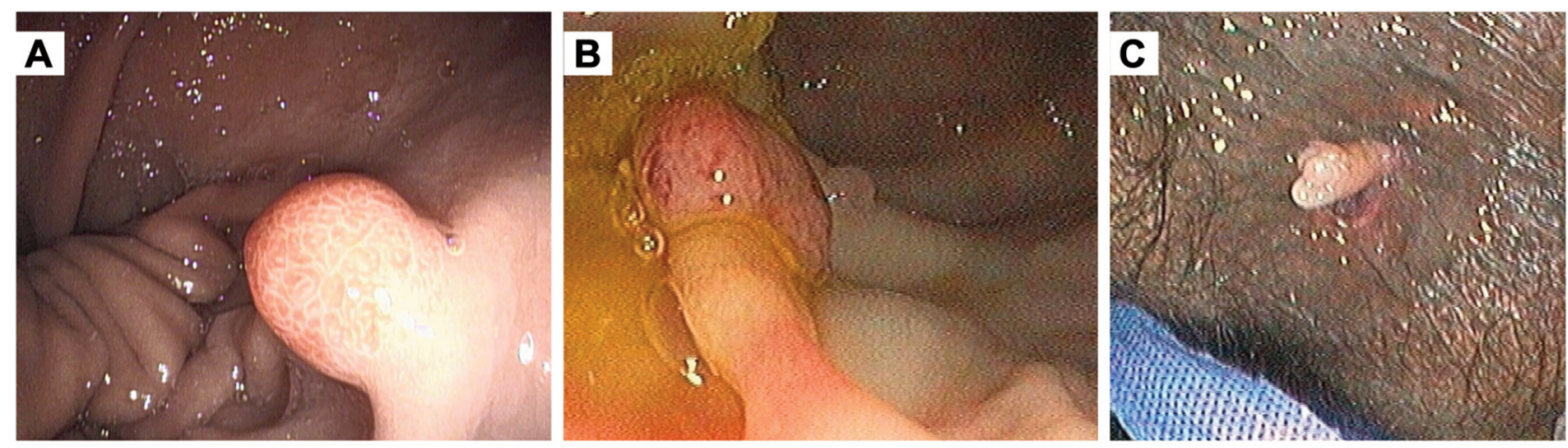

Figure 2. Macroscopic view of Inflammatory fibroid polyp (IFP). A: Gastroscopy demonstrating a reddish IFP of the antrum. B: Colonoscopy demonstrating a pedunculated and reddish IFP of the cecum. C: Pedunculated IFP of the rectum.
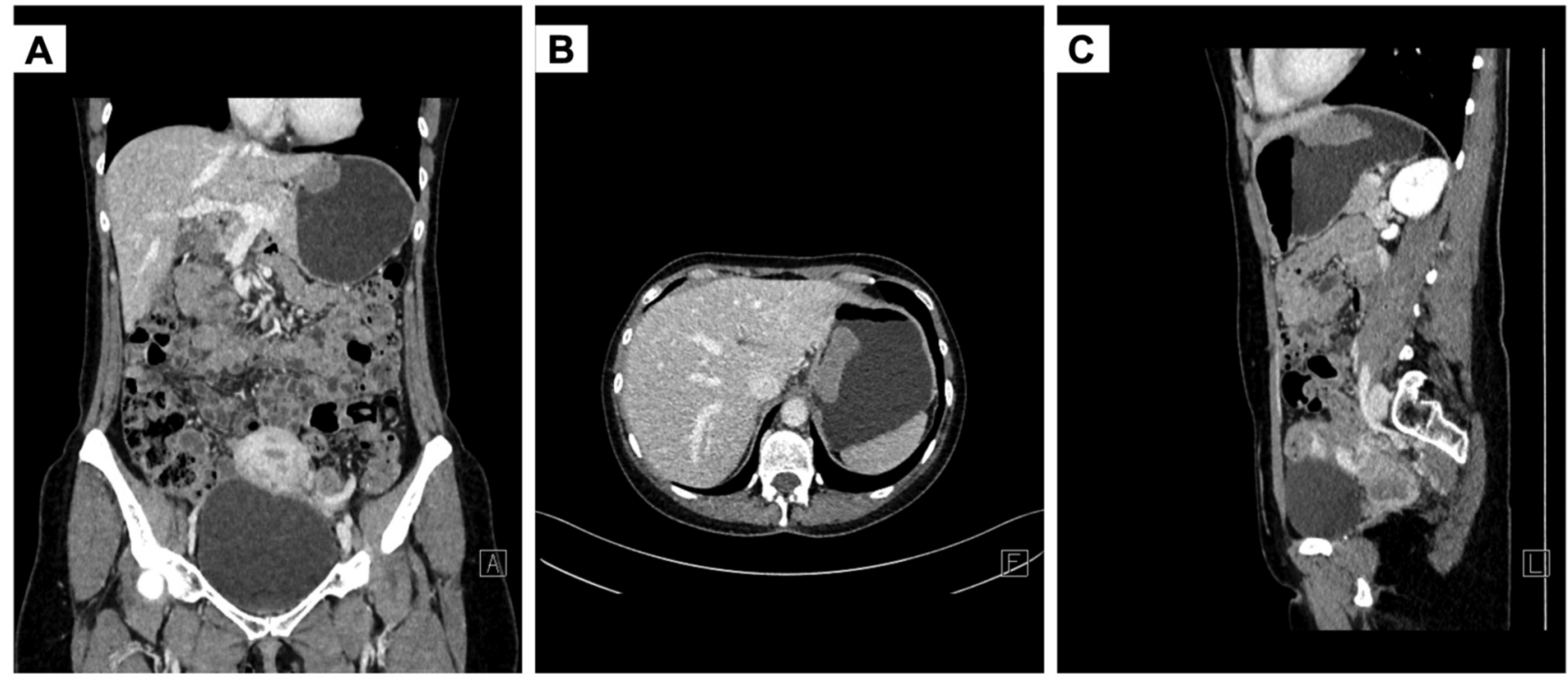

Figure 3. Abdominal computed tomography demonstrating an inflammatory fibroid polyp of the lesser curvature of the stomach. A: Coronal section; $B$ : transverse section; $C$ : sagittal section.

possible names reflects our ignorance on the exact mechanism of IFP development and the different hypotheses on the etiology of IFP. Local infection, allergic reaction, autoimmune processes or excessive host response to an unknown stimulus have all been described as possible causes of IFP development $(5,6)$. Due to its unknown etiology, the malignant potential of what is otherwise described as a benign tumor is currently under debate. Familial occurrence or concomitant development of IFP and other GI malignancies show that some malignant potential might be present, although it is infrequent (7-10). Immunohistologically, IFPs are characterized by spindle cells with unclear origin, positive for CD34 and vimentin, and negative for CD117 $(11,12)$. The overexpression of platelet-derived growth factor receptor alpha
(PDGFRA) and oncogenic PDGFRA mutations in the majority of analyzed IFP suggests that this tumor might develop through activated PDGFRA $(13,14)$. A variety of clinical signs and symptoms are linked to IFP, mainly GI bleeding or abdominal pain, but the clinical presentation may significantly vary, and it mimics other pathology.

This article aims to provide an extensive review of the available English literature on IFP.

\section{Materials and Methods}

An extensive search of the PubMed Index was performed for publications with titles or abstracts containing the terms: "inflammatory fibroid polyp" with/without "Vanek". In order to include most of the existing literature in this review, no starting or 
Table I. Gastrointestinal location of recorded inflammatory fibroid polyps in the included studies.

\begin{tabular}{|c|c|c|}
\hline Location & Number of cases & Percentage of total \\
\hline Stomach & 278 & $66.7 \%$ \\
\hline Cardia & 5 & \\
\hline Corpus & 4 & \\
\hline Fundus & 1 & \\
\hline Antrum & 178 & \\
\hline Prepyloric & 7 & \\
\hline Pylorus & 2 & \\
\hline Unspecified & 81 & \\
\hline Esophagus & 8 & $1.7 \%$ \\
\hline Small bowel & 88 & $21.1 \%$ \\
\hline Ileum & 40 & \\
\hline Distal ileum & 11 & \\
\hline Proximal ileum & 1 & \\
\hline Jejunum & 12 & \\
\hline Ileocecal valve & 3 & \\
\hline Unspecified & 21 & \\
\hline Gallbladder & 1 & $0.2 \%$ \\
\hline Duodenum & 2 & $0.5 \%$ \\
\hline Large bowel & 35 & $8.4 \%$ \\
\hline Cecum & 11 & \\
\hline Transverse & 4 & \\
\hline Descending & 4 & \\
\hline Sigmoid & 2 & \\
\hline Rectum & 5 & \\
\hline Unspecified & 9 & \\
\hline Appendix & 3 & $0.7 \%$ \\
\hline Ileo-anal pouch & 1 & $0.2 \%$ \\
\hline Total & 417 & $100 \%$ \\
\hline
\end{tabular}

ending search date were selected. Results were filtered for publications in English and concerning only humans. All references from the identified publications were searched for other nonindexed cases.

Out of 222 publications, 133 were finally included in this review (Figure 1) $(3,8,15-19,20-145)$. A large number of publications $(n=72)$ prior to 1990 could not be electronically retrieved and were excluded. Seventeen were also excluded as they were irrelevant, earlier reviews of the literature, hypotheses, medical images or other types.

\section{Results}

One-hundred and thirty-three publications reported on 417 patients; 158 males $(37.9 \%), 211$ females $(50.6 \%)$ and 49 of unreported gender $(11.8 \%)$. The median age of the patients was 53 years (range $=4-84$ years).

The esophagus was affected by IFP in eight cases $(1.7 \%)$ and most of these cases also involved the cardia or the sphincter. In $66.7 \%$ of all cases, IFP affected the stomach $(n=278)$ (Figure 2). In approximately two-thirds of these cases, the antrum was affected $(n=178)$ (Figure 3A), followed by the prepyloric segment, the cardia, the corpus,
Table II. Number of patients presenting with specific symptoms and signs.

\begin{tabular}{lc}
\hline Presenting symptom or sign & Number of patients \\
\hline Acute intestinal obstruction, & 52 \\
peritonitis, acute abdomen & \\
Abdominal pain & 63 \\
$\quad$ Epigastrium & 11 \\
Right lower quadrant & 5 \\
Lower abdomen & 3 \\
Unspecified & 44 \\
Nausea & 20 \\
Vomiting & 29 \\
Hematemesis & 3 \\
Dysphagia & 4 \\
Melena & 5 \\
Fever & 8 \\
Lower gastrointestinal bleeding & 17 \\
Occult gastrointestinal bleeding & 4 \\
Abdominal cramping, Distention & 13 \\
Anemia & 13 \\
Indigestion & 5 \\
Weight loss & 10 \\
Diarrhea & 6 \\
Constipation & 9 \\
Other & 10 \\
Pneumoperitoneum & 1 \\
Loss of appetite & 4 \\
Cholecystitis & 1 \\
Lower urinary tract symptoms & 1 \\
Arthralgia & 1 \\
Chest discomfort & 1 \\
Epigastric discomfort & \\
Asymptomatic & 26 \\
\hline & \\
&
\end{tabular}

the pylorus and finally the fundus (Table I). The duodenum was rarely affected $(n=2,0.5 \%)$. The small bowel was affected in $21.1 \%(n=88)$ of all cases. In these cases, the IFP was frequently located in the ileum $(n=52)$, followed by the jejunum $(n=12)$. The ileocecal valve was affected in three cases. The large bowel was affected in $8.4 \%$ of cases $(n=35)$ and cecum was the most frequent location of an IFP $(n=11)$ (Figure 3B) followed by the rectum (Figure 3C). There were only two cases of IFP in the appendix $(0.7 \%)$. Other parts of the GI tract were even more rarely affected.

Patient presentation was recorded as close as possible to the original authors' wording; therefore, some symptoms and signs might overlap each other. Pain was recorded to be the most frequent symptom $(17.0 \%)$, closely followed by acute abdominal symptoms (12.8\%). Other frequent symptoms were vomiting $(7.8 \%)$, nausea $(5.4 \%)$, lower GI bleeding (4.5\%), abdominal distension (3.5\%) and anemia (3.5\%). A number of patients $(7.0 \%)$ were asymptomatic and in 10 cases $(2.4 \%)$ findings were incidental. The number of 

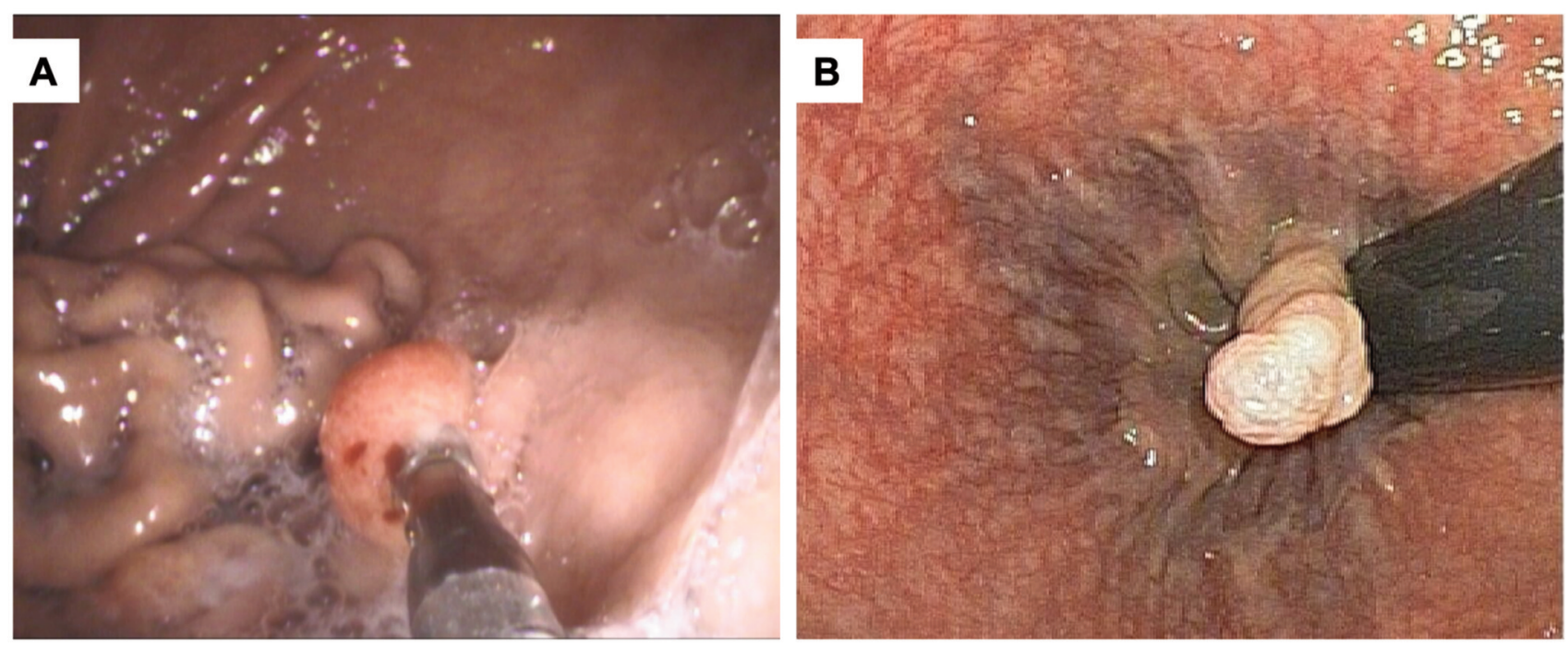

Figure 4. Endoscopic polypectomy. A: Resection of an inflammatory fibroid polyp of the antrum; B: Resection of an inflammatory fibroid polyp of the cecum.

patients presenting with a given symptom can be seen in Table II. No information was given on the presenting complaints of 233 patients $(55.9 \%)$.

Endoscopic polypectomy (Figure 4) was the method of treatment in 85 cases $(20.4 \%)$. Laparotomy and laparoscopy were performed in 49 cases $(11.8 \%)$, followed by further surgical treatment depending on the pathology discovered. Small bowel resection was performed in 35 cases $(8.3 \%)$. Partial or total gastrectomy was performed in 16 cases (3.8\%). Further information on the procedures performed are shown in Table III. There was no information on the treatment method of 238 patients $(57.1 \%)$.

In most cases, histopathology reports were typical of IFP. In a small number of cases, there were significant differences from the expected IFP histopathology and in some of these cases other concomitant malignancy or other GI pathology was present $(10,15-19)$. The majority of pre1990 publications share limited data on the histopathology of the tissue excised during surgery or biopsied by endoscopy. Immunohistochemical reports varied significantly regarding the staining for CD34, CD117, actin, human foreskin fibroblast 35 (HHF-35), CD68 (KP1), macrophage marker antibody (Mac 387), human melanoma black 45 (HMB-45), phosphoglucomutase 1 (PGM1), vimentin, desmin, H-caldesmon, epithelial membrane antigen (EMA), anaplastic lymphoma kinase (ALK1), stem cell factor (SCF), B-cell lymphoma 2 (BCL2), CD21, CD23, human herpesvirus 8 (HHV8), and Epstein-Barr virus (EBER). In the majority of the cases, eosinophils were present in the tissue. Eosinophilia was not present or reported in most cases. CD34 staining was positive in most samples, with a varying intensity.
Table III. Procedure and therapy of inflammatory fibroid polyps.

\begin{tabular}{lc}
\hline Procedure & Number of patients \\
\hline $\begin{array}{l}\text { Endoscopic polypectomy, endoscopic } \\
\text { mucosal resection, endoscopic submucosal }\end{array}$ & 85 \\
resection, endoscopic resection, radical & \\
endoscopic resection & \\
Laparotomy, laparoscopy & 49 \\
Segmental resection of ileum, jejunum, unspecified & 36 \\
Partial or subtotal gastrectomy & 10 \\
Total gastrectomy & 6 \\
Right hemicolectomy & 6 \\
Conservative or medical treatment & 5 \\
Open polypectomy & 4 \\
Ileocecal valve resection & 4 \\
Appendectomy & 3 \\
Refused treatment & 2 \\
Anterior partial fundoplasty & 1 \\
Billroth II & 1 \\
Roux-en-Y & 1 \\
Antrectomy with gastroduodenostomy & 1 \\
Rectal excision & 1 \\
Segmental resection of transverse colon & 1 \\
Segmental resection of duodenum & 1 \\
Laparoscopic cholecystectomy & 1 \\
Laparoscopic atypical gastrectomy & 1 \\
Esophagectomy & 1 \\
Laparoscopic transgastric polypectomy & 1 \\
\hline
\end{tabular}

Helicobacter pylori infection was recorded in four cases $(0.96 \%)$ and it was treated in all of them $(16,72,75,114)$; the remaining studies either reported negative $H$. pylori test or did not report any data on this kind of infection. 

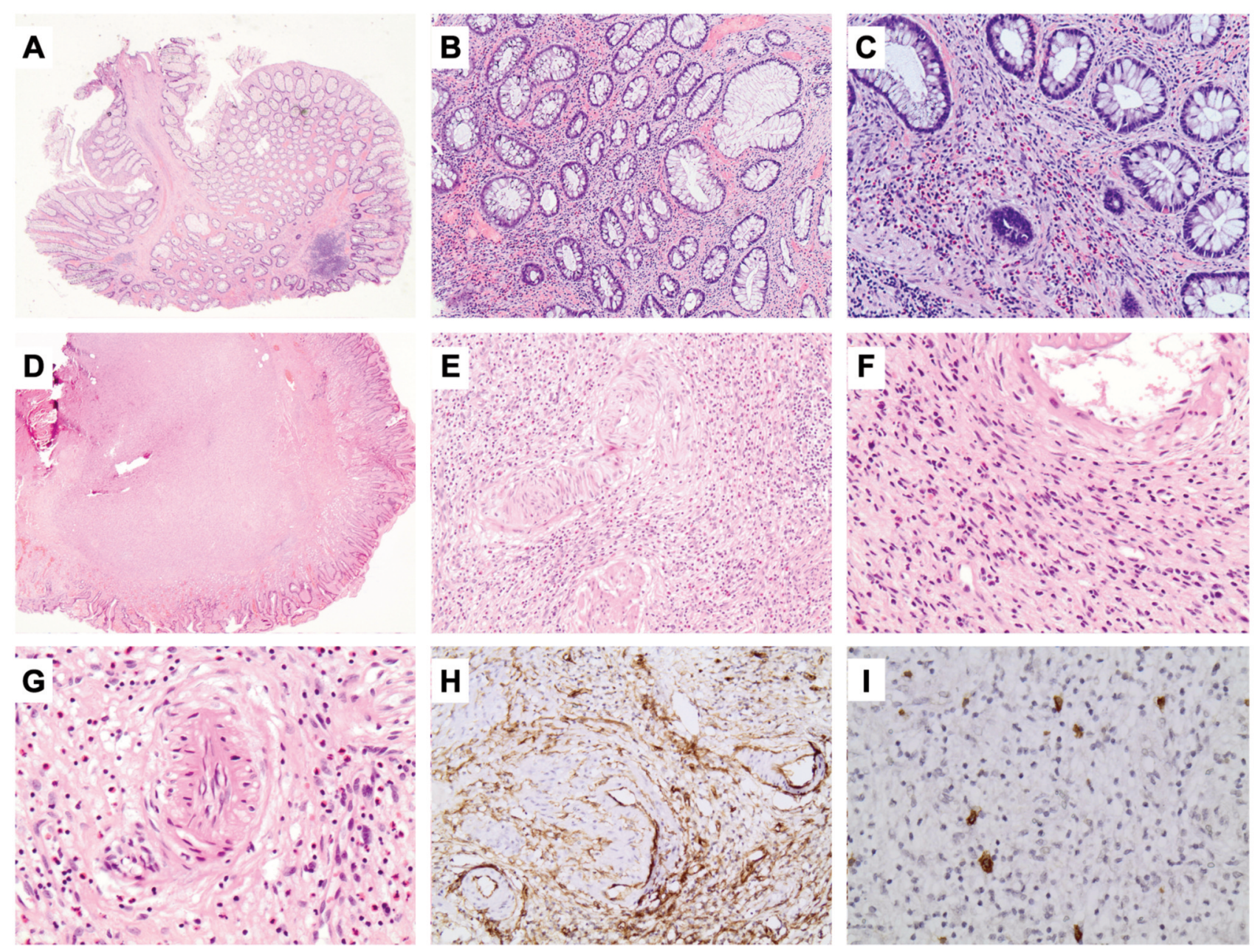

Figure 5. Histological characteristics of inflammatory fibroid polyp (IFP) of the colon (A-C) and stomach (D-I). A: IFP of the colon arising in the submucosa and expanding to the mucosa (hematoxylin-eosin, original magnification $\times 40$ ). B: IFP of colon consisting of a loose fibromyxoid background, inflammatory cells and variably sized blood vessels (hematoxylin-eosin, original magnification $\times 100$ ). C: Bland spindle-shaped mesenchymal cells and heavy inflammatory infiltrate consisting mainly of eosinophils and secondarily of lymphocytes and plasma cells (hematoxylineosin, original magnification $\times 200$ ). D: Submucosal tumor under low-power examination (hematoxylin-eosin, original magnification $\times 20$ ). E, F: The tumor shows a prominent vasculature, large numbers of inflammatory cells, especially eosinophils, and concentrically arranged polygonal to spindle tumor cells around vessels (hematoxylin-eosin, original magnification $\times 100$ and $\times 200$, respectively). G: Multinucleated tumor cells are rarely seen (hematoxylin-eosin, original magnification $\times 400$ ). H: Spindle-shaped tumor cells are positive for CD34 but negative for C-KIT (CD34, original magnification $\times 200$ ). I: Scattered mast cells are depicted (C-KIT, original magnification $\times 200$.

\section{Discussion}

This review follows what has been described in the relevant bibliography $(5,6,11-13,146-150)$.

IFP affects women more frequently (1.3:1 female to male ratio). The median age of patients is - as expected - in the fifth decade of life but a wide range of ages are affected (484 years).

The data from the 417 patients included in our review also confirm that the most commonly affected site of the GI tract is the antrum. In general, the stomach was affected in two- thirds of all cases (67\%). The small bowel was the second most affected organ $(21 \%)$ and colon was the third (8\%). The rest of the GI tract was very rarely affected $(<3 \%$ in total). The few cases of esophageal IFP seem to have involved the lower third of the esophagus and almost always the lower esophageal sphincter or the cardia to some degree.

Despite the fact that some patients remain asymptomatic, IFP tends to present with a variety of different symptoms mimicking other pathology. The asymptomatic cases might be the result of smaller lesions, especially in larger organs (e.g. stomach) where it might take longer for an IFP to cause any 
symptoms. In most cases, patients with IFP presented with either abdominal pain or the clinical picture of acute abdomen in 63 and 52 cases, respectively. Abdominal pain is one of the symptoms of acute abdomen, but in our review these two terms must be distinguished as we tried to follow the authors' description of symptoms. Abdominal cramping and distension were also separately reported in 13 cases. Abdominal pain and acute abdomen were frequently the result of small bowel or ileo-cecal intussusception. Vomiting and nausea were also frequent symptoms in 29 and 20 cases, respectively. Lower GI bleeding and anemia were also frequent in 17 and 13 cases, respectively. In some cases, symptomatic or exuberant anemia was the alerting sign for patients to seek medical advice and discover the underlying cause of IFP. Other symptoms, including atypical ones, were less frequently reported.

Regarding the treatment, patients treated with an endoscopic IFP resection were 85 in total, including all endoscopic methods mentioned in the original texts. In 49 cases, laparotomy was performed, followed by a wide variety of open procedures depending on the localization of the IFP. Despite the fact that the stomach was the most affected organ, gastrectomy of any type was performed in 17 cases, which can be explained by the hypothesis that gastric IFP can often be removed endoscopically. On the other hand, resection of a small bowel segment was more often performed despite the small bowel being affected in a smaller number of cases. This might be the result of technical difficulty of IFP resection during lower GI endoscopy and it is reported that in some cases the polyps especially the larger ones - had to be cut into small pieces in order to be removed or it was impossible for them to be threaded through the endoloop. Table III describes the therapeutic procedures. In all cases, no recurrence was recorded and after initial treatment, no further treatment was necessary $(3,8,15-19,20-145)$.

It is already described in the literature that IFP can be categorized into four histopathological groups: Classical fibrovascular, nodular, sclerotic, and edematous (147). A fifth category of IFP was suggested, that of nuclear pleomorphism, but it is rather atypical. Other authors considered the edematous form as simply a result of edema of the small bowel due to intussusception (148). The natural history of IFP is still unknown but from the wide range of reported polyp sizes and its asymptomatic nature it might be assumed that IFP demonstrates a long and slow growth. During this long period of time, the histology of IFP might change. Smaller lesions have a more marked onion-like distribution of spindle-shaped cells and, as the lesion becomes larger, the tissue architecture changes through the different existing types; furthermore, different histological types can co-exist within the same IFP (148). All the above may explain why histopathology reports from the included studies report a typical IFP picture but they still differ from each other
(Figure 5). Furthermore, not all IFPs stain similarly for CD34, desmin, vimentin, CD117 and other expressed proteins. Although the majority of recorded IFP cases were found to be positive for CD34, still this is not a rule that can exclude IFP from other possible diagnoses. The same is also valid for other protein staining, such as vimentin and CD117 (147, $149,150)$. Based on different tissue staining, some authors conclude that there are different histological varieties of IFP. To make things more complicated, some authors suggest that IFPs have a malignant potential, as malignant processes have been found near or within some IFP $(10,114)$. On the other hand, no well-based evidence exists that confirms this theory.

Even though both epidemiology and the presenting clinical picture have been described in previous publications, this study confirms them, as it includes all the reported data concerning IFP, however, a number of questions remain, including the etiology and the histopathology of IFP. A possible weak point of this literature review is the large number of cases that could not be retrieved and included.

\section{Conclusion}

This study confirms what is already known of the epidemiology and the presenting clinical picture of IFP. From all the above, it is relatively safe to conclude that both the etiology and the timing of diagnosis might change the histopathology and tissue structure of the IFP.

\section{Conflicts of Interest}

All the Authors declare that there are no conflicts of interest.

\section{Authors' Contributions}

$\mathrm{NG}, \mathrm{CD}$ and AG designed the study and wrote the article. NG, CD, AG, VEG, ED, PF, EV, AS, AP and AS collected the data. NT performed the statistical analysis. SS and AL performed the histopathological evaluations. GS performed the radiological evaluations. AA performed the endoscopy. DS, EAA, KK and DD offered scientific advice. NG, CD and AG revised the article. DD critically revised the article and was the supervisor.

\section{References}

1 Vanek J: Gastric submucosal granuloma with eosinophilic infiltration. Am J Pathol 25(3): 397-411, 1949. PMID: 18137133.

2 Helwig EB and Ranier A: Inflammatory fibroid polyps of the stomach. Surg Gynecol Obstet 96(3): 335-367, 1953. PMID: 13038651

3 Johnstone JM and Morson BC: Inflammatory fibroid polyp of the gastrointestinal tract. Histopathology 2(5): 349-361, 1978. PMID: 721077.

4 Nunes MA: Gastric submucosal granuloma (granuloblastoma) with eosinophilic infiltration. Gaz Med Port 3(4): 751-759, 1950. PMID: 14802694. 
5 Shimer GR and Helwig EB: Inflammatory fibroid polyps of the intestine. Am J Clin Pathol 81(6): 708-714, 1984. PMID: 6731350. DOI: $10.1093 /$ ajcp/81 .6.708

6 Ozolek JA, Sasatomi E, Swalsky PA, Rao U, Krasinskas A and Finkelstein SD: Inflammatory fibroid polyps of the gastrointestinal tract: Clinical, pathologic, and molecular characteristics. Appl Immunohistochem Mol Morphol 12(1): 59-66, 2004. PMID: 15163021.

7 Allibone RO, Nanson JK and Anthony PP: Multiple and recurrent inflammatory fibroid polyps in a Devon family ('Devon polyposis syndrome'): An update. Gut 33(7): 10041005, 1992. PMID: 1644320. DOI: 10.1136/gut.33.7.1004

8 Mucientes P, Mucientes F and Klaassen R: Inflammatory fibroid polyp associated with early gastric carcinoma: a case report. Ann Diagn Pathol 16(2): 148-151, 2012. PMID: 21439872. DOI: 10.1016/j.anndiagpath.2011.01.001

9 Spencer D: Recurrent familial inflammatory fibroid polyps of the small intestine. J Clin Pathol 22(6): 743, 1969. PMID: 5365354. DOI: $10.1136 /$ jcp.22.6.743-b

10 Mori M, Tamura S, Enjoji M and Sugimachi K: Concomitant presence of inflammatory fibroid polyp and carcinoma or adenoma in the stomach. Arch Pathol Lab Med 112(8): 829832, 1988. PMID: 3395220.

11 Hasegawa T, Yang P, Kagawa N, Hirose T and Sano T: CD34 expression by inflammatory fibroid polyps of the stomach. Mod Pathol 10(5): 451-456, 1997. PMID: 9160309.

12 Kim MK, Higgins J, Cho EY, Ko YH and Oh YL: Expression of CD34, BCL-2, and KIT in inflammatory fibroid polyps of the gastrointestinal tract. Appl Immunohistochem Mol Morphol 8(2): 147-153, 2000. PMID: 10937062.

13 Schildhaus HU, Cavlar T, Binot E, Buttner R, Wardelmann E and Merkelbach-Bruse S: Inflammatory fibroid polyps harbour mutations in the platelet-derived growth factor receptor alpha (PDGFRA) gene. J Pathol 216(2): 176-182, 2008. PMID: 18686281. DOI: $10.1002 /$ path.2393

14 Stenman G, Eriksson A and Claesson-Welsh L: Human PDGFA receptor gene maps to the same region on chromosome 4 as the KIT oncogene. Genes Chromosomes Cancer 1(2): 155-158, 1989. PMID: 2562117.

15 Zissis D, Zizi-Serbetzoglou A, Grammatoglou X, Glava C, Katsamagkou E, Nikolaidou ME and Vasilakaki T: Combined carcinoid and mixed (composite) glandular - endocrine cell carcinoma of the stomach in atrophic gastritis. J BUON 14(1): 127-130, 2009. PMID: 19365883.

16 Sakran N, Farkash I and Hershko D: Inflammatory fibroid polyp (Vanek's tumour) causing a rare form of double invagination intussusception of the small bowel. ANZ J Surg 88(1-2): E85E86, 2018. PMID: 26386365. DOI: 10.1111/ans.13261

17 Jin JS, Wu CS, Yeh CH, Huang BP and Tsao TY: Inflammatory fibroid polyp of rectum mimicking rectal cancer. Kaohsiung $\mathbf{J}$ Med Sci 29(8): 460-463, 2013. PMID: 23906237. DOI: 10.1016/ j.kjms.2012.12.007

18 Acar T, Harman M, Guneyli S and Elmas N: Co-occurrence of inflammatory fibroid polyp in Crohn's disease: A MR enterography study. Turk J Gastroenterol 26(4): 361-362, 2015. PMID: 26039011. DOI: 10.5152/tjg.2015.0191

19 Parasi A, Triantafillidis JK, Barbatzas C, Karakosta A, Condilis N and Sotiriou H: Coexistence of Crohn's disease and inflammatory fibroid polyp of the small bowel. Report of a case and review of the literature. Ann Ital Chir 76(4): 395-399, 2005. PMID: 16550878.
20 McGregor JC and Rao SS: Inflammatory fibroid polyp of the ileum-a rare cause of intussusception. Postgrad Med J 52(604): 89-91, 1976. PMID: 1264930. DOI: 10.1136/pgmj. 52.604 .89

21 Allman RM, Cavanagh RC, Helwig EB and Lichtenstein JE: Radiologic-pathologic correlation from the Armed Forces Institute of Pathology. Inflammatory fibroid polyp. Radiology 127(1): 69-73, 1978. PMID: 635208. DOI: 10.1148/127.1.69

22 Suen KC and Burton JD: The spectrum of eosinophilic infiltration of the gastrointestinal tract and its relationship to other disorders of angiitis and granulomatosis. Hum Pathol 10(1): 31-43, 1979. PMID: 428993.

23 Huszar M, Zurkowski Z, Winter S, Herczeg E and Weissberg D: Inflammatory fibroid polyp of the small intestine. JAMA 243(7): 651, 1980. PMID: 7351799.

24 Nkanza NK, King M and Hutt MS: Intussusception due to inflammatory fibroid polyps of the ileum: a report of 12 cases from Africa. Br J Surg 67(4): 271-274, 1980. PMID: 7388310.

25 Williams RM: An ultrastructural study of a jejunal inflammatory fibroid polyp. Histopathology 5(2): 193-203, 1982. PMID: 7216180.

26 Ferin P and Skucas J: Inflammatory fibroid polyp of the colon simulating malignancy. Radiology 149(1): 55-56, 1983. PMID: 6611950. DOI: 10.1148/radiology.149.1.6611950

27 Pollice L and Bufo P: Inflammatory fibroid polyp of the rectum. Pathol Res Pract 178(5): 508-512, 1984. PMID: 6462954. DOI: $10.1016 / \mathrm{S} 0344-0338(84) 80012-6$

28 Assarian GS and Sundareson A: Inflammatory fibroid polyp of the ileum. Hum Pathol 16(3): 311-312, 1985. PMID: 3972408.

29 Hanada M, Takami M, Hirata K and Nakajima T: Hyalinoid giant cell gastritis. A unique gastric lesion associated with eosinophilic hyalinoid degeneration of smooth muscle. Acta Pathol Jpn 35(3): 749-758, 1985. PMID: 2412393.

30 Niv Y and Hurwitz A: Inflammatory fibroid polyp of the cecum, associated with adenomatous polyp and ovarian thecoma. Isr J Med Sci 21(7): 624-626, 1985. PMID: 2995276.

31 Carlen B and Willen R: Inflammatory fibroid polyp of the ileum. Case report. Acta Chir Scand 154(4): 325-327, 1988. PMID: 3376695.

32 Sampson MA, Lyons TJ, Nottingham J and Naik D: Ultrasound diagnosis of recurrent intussusception due to inflammatory fibroid polyp of the ileum. J Ultrasound Med 9(7): 423-425, 1990. PMID: 2197426.

33 Stolte $\mathrm{M}$ and Finkenzeller G: Inflammatory fibroid polyp of the stomach. Endoscopy 22(5): 203-207, 1990. PMID: 2242737. DOI: $10.1055 / \mathrm{s}-2007-1012848$

34 Dawson PM, Shousha S and Burn JI: Inflammatory fibroid polyp of the small intestine presenting as intussusception. Br J Clin Pract 44(11): 495-497, 1990. PMID: 2282305.

35 Tada S, Iida M, Yao T, Matsui T, Kuwano Y, Hasuda S and Fujishima M: Endoscopic removal of inflammatory fibroid polyps of the stomach. Am J Gastroenterol 86(9): 1247-1250, 1991. PMID: 1882805.

36 Williams GR, Jaffe S and Scott CA: Inflammatory fibroid polyp of the terminal ileum presenting in a patient with active Crohn's disease. Histopathology 20(6): 545-547, 1992. PMID: 1607157.

37 Adachi Y, Mori M, Iida M, Tsuneyoshi M and Sugimachi K: Inflammatory fibroid polyp of the stomach. Report of three unusual cases. J Clin Gastroenterol 15(2): 154-158, 1992. PMID: 1401828. 
38 Mori M, Kakeji Y, Adachi Y, Korenaga D and Sugimachi K: Non-polypoid inflammatory fibroid polyps concomitant with early carcinoma in the stomach. Eur J Surg Oncol 18(6): 632635, 1992. PMID: 1478298.

39 Kojimahara K, Mukai M, Yamazaki K, Yamada T, Katayama T, Nakada K, Uematsu S, Umezono A and Hosoda Y: Inflammatory pseudotumor of the stomach: report of a highly infiltrative case with electron microscopic and immunohistochemical studies. Acta Pathol Jpn 43(1-2): 65-70, 1993. PMID: 8465658.

40 Kolodziejczyk P, Yao $\mathrm{T}$ and Tsuneyoshi M: Inflammatory fibroid polyp of the stomach. A special reference to an immunohistochemical profile of 42 cases. Am J Surg Pathol 17(11): 1159-1168, 1993. PMID: 8214261.

41 Kim JS, Kwon SY, Byun KS, Bak YT, Kim JH, Kim JG, Lee $\mathrm{CH}$, Ryu JW and Won NH: Jejunal inflammatory fibroid polyp presenting as intussusception-a case report with review of the literature. Korean J Intern Med 9(1): 51-54, 1994. PMID: 8038148. DOI: $10.3904 / \mathrm{kjim} .1994 .9 .1 .51$

42 Ling CC, Hsu TC, Shih SC, Kao CR, Chou SY and Huang SH: Inflammatory fibroid polyp of the jejunum causing intussusception: A case report. Zhonghua Yi Xue Za Zhi 53(2): 127-130, 1994. PMID: 8167990.

43 Tysk C, Schnurer LB and Wickbom G: Obstructing inflammatory fibroid polyp in pelvic ileal reservoir after restorative proctocolectomy in ulcerative colitis. Report of a case. Dis Colon Rectum 37(10): 1034-1037, 1994. PMID: 7924712.

44 Bosch O, Gonzalez Campos C, Jurado A, Guijo I, Miro C, Renedo $\mathrm{G}$ and Porres JC: Esophageal inflammatory fibroid polyp. Endoscopic and radiologic features. Dig Dis Sci 39(12): 2561-2566, 1994. PMID: 7995180

45 Widgren $\mathrm{S}$ and Cox $\mathrm{JN}$ : Inflammatory fibroid polyp in a continent ileo-anal pouch after colectomy for ulcerative colitiscase report. Pathol Res Pract 193(9): 643-647; discussion 649652, 1997. PMID: 9521023. DOI: 10.1016/S03440338(97)80044-1

46 Bandyopadhyay PK, Ishaq N, Malik AK and Mahroos S: Inflammatory fibroid polyp of proximal ileum causing recurrent intussusception. Br J Clin Pract 51(2): 125-126, 1997. PMID: 9158259.

47 Matsushita M, Hajiro K, Okazaki K and Takakuwa H: Gastric inflammatory fibroid polyps: Endoscopic ultrasonographic analysis in comparison with the histology. Gastrointest Endosc 46(1): 53-57, 1997. PMID: 9260706.

48 Kuestermann SA, Saleeb SF and Teplick SK: General case of the day. Jejunal intussusception caused by an inflammatory fibroid polyp (IFP). Radiographics 19(2): 539-541, 1999. PMID: 10194795. DOI: 10.1148/radiographics.19.2.g99mr19539

49 Nakase H, Mimura J, Kawasaki T, Itani T, Komori H, Hashimoto $\mathrm{K}$, Okazaki $\mathrm{K}$ and Chiba T: Endoscopic resection of small inflammatory fibroid polyp of the colon. Intern Med 39(1): 2527, 2000. PMID: 10674844. DOI: 10.2169/internalmedicine. 39.25

50 Costa PM, Marques A, Tavora, Oliveira E and Diaz M: Inflammatory fibroid polyp of the esophagus. Dis Esophagus 13(1): 75-79, 2000. PMID: 11005337. DOI: 10.1046/j.14422050.2000.00086.x

51 Balci NC, Radjazi S and Polat H: Adult intussusception secondary to inflammatory fibroid polyp: Demonstration by
MRI: Eur Radiol 10(11): 1708-1710, 2000. PMID: 11097392. DOI: $10.1007 / \mathrm{s} 003300000508$

52 Miettinen M and Sobin LH: Gastrointestinal stromal tumors in the appendix: A clinicopathologic and immunohistochemical study of four cases. Am J Surg Pathol 25(11): 1433-1437, 2001. PMID: 11684962.

53 Sah SP, Agrawal CS and Rani S: Inflammatory fibroid polyp of the jejunum presenting as intussusception. Indian $\mathrm{J}$ Pathol Microbiol 45(1): 119-121, 2002. PMID: 12593579.

54 Savargaonkar P, Morgenstern N and Bhuiya T: Inflammatory fibroid polyp of the ileum causing intussusception: Report of two cases with emphasis on cytologic diagnosis. Diagn Cytopathol 28(4): 217-221, 2002. PMID: 12672099. DOI: $10.1002 / \mathrm{dc} .10258$

55 Hirasaki S, Endo H, Nishina T, Masumoto T, Tanimizu M and Hyodo I: Gastric cancer concomitant with inflammatory fibroid polyp treated with endoscopic mucosal resection using an insulation-tip diathermic knife. Intern Med 42(3): 259-262, 2003. PMID: 12705791. DOI: 10.2169/internalmedicine.42.259

56 Nishiyama Y, Koyama S, Andoh A, Kishi Y, Yoshikawa K, Ishizuka I, Yokono T and Fujiyama Y: Gastric inflammatory fibroid polyp treated with Helicobacter pylori eradication therapy. Intern Med 42(3): 263-267, 2003. PMID: 12705792. DOI: 10.2169 /internalmedicine.42.263

57 Fuke H, Hashimoto A, Shimizu A, Yoshimura H, Nakano T and Shiraki K: Computed tomographic image of an inflammatory fibroid polyp of the stomach. Clin Imaging 27(6): 400-402, 2003. PMID: 14585568.

58 Daum O, Hes O, Vanecek T, Benes Z, Sima R, Zamecnik M, Mukensnabl P, Hadravska S, Curik R and Michal M: Vanek's tumor (inflammatory fibroid polyp). Report of 18 cases and comparison with three cases of original Vanek's series. Ann Diagn Pathol 7(6): 337-347, 2003. PMID: 15018116.

59 Chongsrisawat V, Yimyeam P, Wisedopas N, Viravaidya D and Poovorawan Y: Unusual manifestations of gastric inflammatory fibroid polyp in a child. World J Gastroenterol 10(3): 460-462, 2004. PMID: 14760782. DOI: 10.3748/ wjg.v10.i3.460

60 Zinkiewicz K, Zgodzinski W, Dabrowski A, Szumilo J, Cwik $\mathrm{G}$ and Wallner G: Recurrent inflammatory fibroid polyp of cardia: A case report. World J Gastroenterol 10(5): 767-768, 2004. PMID: 14991958. DOI: 10.3748/wjg.v10.i5.767

61 Miyata T, Yamamoto H, Kita H, Yano T, Sunada K, Sekine Y, Iwamoto M, Kuno A, Onishi N, Ido K, Nokubi M, Tanaka A and Sugano K: A case of inflammatory fibroid polyp causing small-bowel intussusception in which retrograde double-balloon enteroscopy was useful for the preoperative diagnosis. Endoscopy 36(4): 344-347, 2004. PMID: 15057687. DOI: 10.1055/s-2004-814305

62 Maeng L, Choi KY, Lee A, Kang CS and Kim KM: Polypoid arteriovenous malformation of colon mimicking inflammatory fibroid polyp. J Gastroenterol 39(6): 575-578, 2004. PMID: 15235876. DOI: $10.1007 / \mathrm{s} 00535-003-1345-y$

63 Gönül II, Erdem O and Ataoğlu O: Inflammatory fibroid polyp of the ileum causing intussusception: a case report. Turk J Gastroenterol 15(1): 59-62, 2004. PMID: 15264125.

64 Santos Gda C, Alves VA, Wakamatsu A and Zucoloto S: Inflammatory fibroid polyp: an immunohistochemical study. Arq Gastroenterol 41(2): 104-107, 2004. PMID: 15543383. DOI: /S0004-28032004000200007 
65 Aydin A, Tekin F, Gunsar F and Tuncyurek M: Gastric inflammatory fibroid polyp. Gastrointest Endosc 60(5): 802803, 2004. PMID: 15557964

66 Vijayaraghavan R, Sujatha Y, Santosh KV and Belagavi CS: Inflammatory fibroid polyp of jejunum causing jejuno-jejunal intussusception. Indian J Gastroenterol 23(5): 190-192, 2004. PMID: 15599009.

67 Ng C, Lam KY, Gupta TS and Ho YH: Inflammatory fibroid polyp of the caecum in a patient with neurofibromatosis. Ann Acad Med Singapore 33(6): 797-799, 2004. PMID: 1560 8842 .

68 Hirasaki S, Tanimizu M, Tsubouchi E, Nasu J and Masumoto T: Gastritis cystica polyposa concomitant with gastric inflammatory fibroid polyp occurring in an unoperated stomach. Intern Med 44(1): 46-49, 2005. PMID: 15704662. DOI: 10.2169 /internalmedicine.44.46

69 Sakamoto T, Kato H, Okabe T, Ohya T, Iesato H, Yokomori T and Haga SS: A large inflammatory fibroid polyp of the colon treated by endoclip-assisted endoscopic polypectomy: A case report. Dig Liver Dis 37(12): 968-972, 2005. PMID: 16243012. DOI: 10.1016/j.dld.2005.03.014

70 Kim SG, Choi KD, Kim JS, Jung HC and Song IS: Ileal inflammatory fibroid polyp: A rare cause of obscure gastrointestinal bleeding diagnosed by wireless capsule endoscopy. Dig Dis Sci 51(5): 906-908, 2006. PMID: 16758313. DOI: $10.1007 / \mathrm{s} 10620-006-9338-3$

71 Iwamoto K, Sakashita M, Takahashi T, Obata D, Tanaka S, Fujii $\mathrm{M}$ and Okabayashi Y: Depressed type of inflammatory fibroid polyp of the colon. Int J Colorectal Dis 22(11): 1409, 2007. PMID: 16804668. DOI: 10.1007/s00384-006-0180-z

72 Hirasaki S, Matsubara M, Ikeda F, Taniguchi H and Suzuki S: Gastric inflammatory fibroid polyp treated with Helicobacter pylori eradication therapy. Intern Med 46(12): 855-858, 2007. PMID: 17575378. DOI: 10.2169/internalmedicine.46.6445

73 Hirasaki S, Matsubara M, Ikeda F, Taniguchi H and Suzuki S: Inflammatory fibroid polyp occurring in the transverse colon diagnosed by endoscopic biopsy. World J Gastroenterol 13(27): 3765-3766, 2007. PMID: 17659744. DOI: 10.3748/wjg.v13. i27.3765

74 Park YB, Cheung DY, Kim JI, Park SH, Cho SH, Han JY, Kim JK and Choi KY: A large inflammatory fibroid polyp in the sigmoid colon treated by endoscopic resection. Inter Med 46(19): 1647-1649, 2007. PMID: 17917327. DOI: 10.2169/ internalmedicine.46.0081

75 Paikos D, Moschos J, Tzilves D, Koulaouzidis A, Kouklakis G, Patakiouta F, Kontodimou K, Tarpagos and Katsos I: Inflammatory fibroid polyp or Vanek's tumour. Dig Surg 24(3): 231-233, 2007. PMID: 17541268. DOI: 10.1159/ 000103326

76 Tanaka K, Toyoda H, Imoto I, Hamada Y, Aoki M, Kosaka R, Noda T and Takei Y: Anemia caused by a gastric inflammatory fibroid polyp. Gastrointest Endosc 67(2): 345-346, 2008. PMID: 18155207. DOI: 10.1016/j.gie.2007.08.029

77 Kan H, Suzuki H, Shinji S, Naito Z, Furukawa K and Tajiri T: Case of an inflammatory fibroid polyp of the cecum. J Nippon Med Sch 75(3): 181-186, 2008. PMID: 18648178.

78 Costamagna D, Erra S, Zullo A, Servente G and Durando R: Small bowel intussusception secondary to inflammatory fibroid polyp of the ileum: Report of a case. Chir Ital 60(2): 323-327, 2008. PMID: 18689187.
79 Bhatti I, Melhado R, Leeder P, Semeraro D and Tierney G: Clinical challenges and images in GI: Image 3: Inflammatory fibroid polyp. Gastroenterology 135(5): 1465, 1808, 2008. PMID: 18851972. DOI: $10.1053 /$ j.gastro.2008.10.008

80 Shimura T, Kataoka H, Sasaki M, Kubota E, Shiraki S, Matsusako K, Nakayama Y, Mizoshita T, Mizushima T and Joh T: Rectal inflammatory fibroid polyp resected with endoscopic submucosal dissection. Intern Med 47(23): 2029-2031, 2008 PMID: 19043255, DOI: 10.2169/internalmedicine.47.1357

81 Kim BC, Cheon JH, Lee SK, Kim TI, Kim H and Kim WH: Needle knife-assisted endoscopic polypectomy for a large inflammatory fibroid colon polyp by making its stalk into an omega shape using an endoloop. Yonsei Med J 49(4): 680-686, 2008. PMID: 18729316. DOI: 10.3349/ymj.2008.49.4.680

82 Ramachandra S, Lapsia S, Latifaj B and Ghai S: A rare cause of anaemia (2008: 3b). Eur Radiol 18(6): 1300-1302, 2008 PMID: 18463878. DOI: 10.1007/s00330-007-0775-y

83 Calabuig-Fariñas S, Lopez-Guerrero JA, Ribera MJ, Navarro S, Ramos D, Pellin A and Liombart-Bosch A: Inflammatory fibroid polyp of the small bowel with a mutation in exon 12 of PDGFR alpha. Virchows Arch 454(3): 327-331, 2009. PMID: 19189127. DOI: $10.1007 / \mathrm{s} 00428-008-0715-5$

84 Ruffolo C, Scarpa M, Bassi D and Angriman I: Inflammatory fibroid polyp causing intestinal obstruction following restorative proctocolectomy for ulcerative colitis. Dig Surg 26(4): 285-286, 2009. PMID: 19590208 . DOI: $10.1159 / 000227767$

85 Wolff JH, Twaddell WS and Darwin PE: Endoscopic resection of an ileal inflammatory fibroid polyp using retrograde singleballoon enteroscopy. Clin Gastroenterol Hepatol 7(11): E66E67, 2009. PMID: 19602451. DOI: 10.1016/j.cgh.2009.07.004

86 Yamane T, Uchiyama K, Ishii T, Ishii H, Takizawa R, Omura $\mathrm{M}$, Fujise $\mathrm{K}$ and Tajiri $\mathrm{H}$ : Case of inflammatory fibroid polyp of the esophagogastric junction. Dig Endosc 21(2): 97-100, 2009. PMID: 19691782. DOI: 10.1111/j.1443-1661.2009. 00833.x

87 Doğanavsargil B, Serin G, Akyildiz M, Ertan Y and Tunçyürek M: Benign fibroblastic polyp of the colon: A case report. Turk J Gastroenterol 20(4): 287-290, 2009. PMID: 20084575. DOI: 10.4318/tjg.2009.0029

88 Yen HH and Chen CJ: Education and Imaging. Gastrointestinal: endoscopic submucosal dissection for gastric inflammatory fibroid polyp. J Gastroenterol Hepatol 25(8): 1465, 2010 PMID: 20659241. DOI: 10.1111/j.1440-1746.2010.06424.x

89 Yamashita K, Arimura Y, Tanuma T, Endo T, Hasegawa T and Shinomura Y: Pattern of growth of a gastric inflammatory fibroid polyp with PDGFRA overexpression. Endoscopy 43 Suppl 2 UCTN: E171-E172, 2011. PMID: 21563068, DOI: $10.1055 / \mathrm{s}-0030-1256289$

90 Saritaş Ü, Üstündağ and Gedıkoğlu G: Successful endoscopic treatment of huge gastric inflammatory fibroid polyp. Turk J Gastroenterol 22(2): 224-226, 2011. PMID: 21796566. DOI: 10.4318/tjg.2011.0199

91 Woodward K, Gangarosa LM and Hunt HV: Gastric inflammatory fibroid polyp. Indian J Pathol Microbiol 54(3): 622-623, 2011 PMID: 21934242. DOI: 10.4103/0377-4929.85120

92 Morales-Fuentes GA, de Arino-Suarez M, Zarate-Osorno A, Rodriguez-Jerkov J, Terrazas-Espitia F and Perez-Manauta J: Vanek's polyp or inflammatory fibroid polyp. Case report and review of the literature. Cir Cir 79(3): 242-245, 263-267, 2011. PMID: 22380995. 
93 Segovia-Lohse HA: Adult intussusception with perforation and secondary peritonitis. Case report. Cir Cir 79(3): 252-255, 274277, 2011. PMID: 22380997.

94 Ishibashi H, Aoyagi K, Kobayashi H, Kurahara K, Kominato K, Kawasaki K, Oshiro Y and Fuchigami T: Endoscopic mucosal resection of inflammatory fibroid polyp in the transverse colon. Endoscopy 44 Suppl 2 UCTN: E15-E16, 2012. PMID: 22396254. DOI: 10.1055/s-0031-1291499

95 Ergun M, Zengin N and Kayacetin E: Loop observe and snare technique for endoscopic resection of a gastric inflammatory fibroid polyp. Endoscopy 44 Suppl 2 UCTN: E86-E87, 2012. PMID: 22396297. DOI: 10.1055/s-0031-1291640

96 McCawley N, Sheahan K and Hanly AM: Endoscopic resection of a large inflammatory fibroid polyp of the caecum. Colorectal Dis 15(2): E99-E100, 2013. PMID: 22759279. DOI: 10.1111/ j.1463-1318.2012.03163.x

97 Rossi P, Montuori M, Balassone V, Ricciardi E, Anemona L, Manzelli A and Petrella G: Inflammatory fibroid polyp. A case report and review of the literature. Ann Ital Chir 83(4): 347351, 2012. PMID: 22759473.

98 Akbulut S: Intussusception due to inflammatory fibroid polyp: A case report and comprehensive literature review. World $\mathrm{J}$ Gastroenterol 18(40): 5745-5752, 2012. PMID: 23155316. DOI: $10.3748 / w j g . v 18 . i 40.5745$

99 Tudose I, Andrei F, Calu V, Staniceanu F and Miron A: Giant inflammatory fibroid polyp. Rom J Intern Med 50(2): 179-185, 2012. PMID: 23326963.

100 Lasithiotakis K, Grisbolaki E, Filis D, Athanasakis I, Zoras O and Chalkiadakis G: Ileocolic intussusception precipitated by diagnostic colonoscopy: A case report. Surg Laparosc Endosc Percutan Tech 22(3): E161-E163, 2012. PMID: 22678343. DOI: 10.1097/SLE.0b013e31824b230f

101 Rabbani K, Narjis Y, Jgounni R, Semlani Z, Difaa A, Benelkhaiat R, Louzi A and Finech B: Adult intussusception caused by an inflammatory fibroid ileal polyp. Acta Chir Belg 112(2): 157-159, 2012. PMID: 22571080.

102 Ali WA, Mahmud AM and Keloth TR: Incidental finding of inflammatory fibroid polyp of the appendix in a patient presenting with acute appendicitis. Indian J Gastroenterol 32(2): 130-132, 2013. PMID: 23296597. DOI: 10.1007/s12664-0120292-Z

103 Martini M, Santoro L, Familiari P, Costamagna G and Ricci R: Inflammatory fibroid polyp of the gallbladder bearing a platelet-derived growth factor receptor alpha mutation. Arch Pathol Lab Med 137(5): 721-724, 2013. PMID: 23627457. DOI: 10.5858/arpa.2012-0218-CR

104 He HY, Shen ZB, Fang Y, Sun YH and Qin XY: Bleeding and hyperpyrexia in an adult with gastric inflammatory fibroid polyp. Chin Med J 126(13): 2594, 2013. PMID: 23823846.

105 Kayyali A, Toumeh A, Ahmad U, De Las Casas LE and Nawras A: Giant inflammatory fibroid polyp of the descending colon treated with endoscopic resection. ACG Case Rep J 1(1): 3639, 2013. PMID: 26157816. DOI: 10.14309/crj.2013.14

106 Neishaboori H, Maleki I and Emadian O: Jejunal intussusception caused by a huge Vanek's tumor: A case report. Gastroenterol Hepatol Bed Bench 6(4): 210-213, 2013. PMID: 24834274.

107 Teli B, Cp M, S S and Mv S: Ileo-ileal intussusception in an adult caused by Vanek's tumour: A rare case report. J Clin Diagn Res 7(12): 2994-2995, 2013. PMID: 24551704. DOI: 10.7860/JCDR/2013/6863.3821
108 Sulu B, Günerhan Y and Kösemehmetoğlu K: A rare ileal tumor causing anemia and intussusception: Inflammatory fibroid polyp. Turkish J Gastroenterol 25(1): 116-117, 2014. PMID: 24918146. DOI: $10.5152 /$ tjg.2014.3654

109 Joyce KM, Waters PS, Waldron RM, Khan I, Orosz ZS, Nemeth $\mathrm{T}$ and Barry K: Recurrent adult jejuno-jejunal intussusception due to inflammatory fibroid polyp - Vanek's tumour: A case report. Diagn Pathol 9: 127, 2014. PMID: 24968941. DOI: 10.1186/1746-1596-9-127

110 Nerli RB, Jali SM, Guntaka AK, Malur PR, Anita B and Hiremath MB: Giant inflammatory fibroid polyp of the terminal ileum presenting with lower urinary tract symptoms: Case report. Indian J Cancer 51(4): 541-542, 2014. PMID: 26842189. DOI: $10.4103 / 0019-509 X .175304$

111 Jukic Z, Ferencic Z, Radulovic P, Mijic A and Fucic A: Estrogen and androgen receptors in inflammatory fibroid polyp (Vanek's tumor): Case report. Anticancer Res 34(12): $7203-$ 7206, 2014. PMID: 25503150.

112 Feldis M, Dilly M, Marty M, Laurent F and Cassinotto C: An inflammatory fibroid polyp responsible for an ileal intussusception discovered on an MRI. Diagn Interv Imaging 96(1): 89-92, 2015. PMID: 24618561. DOI: 10.1016/j.diii. 2014.01.013

113 Sanchez-Cifuentes A, Gonzalez-Valverde FM, Ruiz-Marin M, Pena-Ros E, Vicente-Ruiz M, Martinez-Sanz N, EscamillaSegade C, Pastor-Quirante F and Albarracin-Marin-Blazquez A: Inflammatory fibroid polyp of the appendix or Vanek's tumor. Rev Esp Enferm Dig 107(1): 37-38, 2015. PMID: 25603330.

114 Mitsui Y, Kagemoto K, Itagaki T, Inoue S, Naruse K, Muguruma $\mathrm{N}$ and Takayama T: Gastric inflammatory fibroid polyp morphologically changed by Helicobacter pylori eradication. Clin J Gastroenterol 8(2): 77-81, 2015. PMID: 25733031. DOI: $10.1007 / \mathrm{s} 12328-015-0557-\mathrm{z}$

115 Kimura N, Hight M, Liang J, Willy R, Liang K and Camp J: Adult intussusception secondary to inflammatory fibroid polyp. West J Emerg Med 16(4): 581-582, 2015. PMID: 26265975. DOI: $10.5811 /$ westjem.2015.4.26399

116 Smith-Chakmakova F, Liu YJ and Karamchandani DM: Inflammatory fibroid polyp of the ileocecal valve: Case report, review, and recent advances. Ann Clin Lab Sci 45(4): 441-445, 2015. PMID: 26275697.

117 Hiremath S, Nanjappa N and Kamath S: Inflammatory fibroid polyp (IFP) of the terminal ileum presenting as acute intestinal obstruction without intussusception. BMJ Case Rep 2015: bcr2015211029, 2015. PMID: 26347236. DOI: 10.1136/bcr2015-211029

118 Han GJ, Kim JH, Lee SS, Park SH, Lee JS and Ha HK: Inflammatory fibroid polyps of the gastrointestinal tract: A 14year CT study at a single institution. Abdom Imaging 40(7): 2159-2166, 2015. PMID: 25896613. DOI: 10.1007/s00261-0150431-y

119 Pinto-Pais T, Fernandes S, Proença L, Fernandes C, Ribeiro I, Sanches A, Carvalho J and Fraga J: A large gastric inflammatory fibroid polyp. GE Port J Gastroenterol 22(2): 6164, 2015. PMID: 28868375. DOI: 10.1016/j.jpge.2014.07.006

120 Laskaratos FM, Vlachou E, Luong TV, Wylie P, Hamilton MI, Murray CD and Despott EJ: Endoscopic resection of a giant ileal inflammatory fibroid polyp by retrograde double-balloon enteroscopy. Endoscopy 48 Suppl 1 UCTN: E14-E15, 2016. PMID: 26800193. DOI: 10.1055/s-0035-1569649 
121 Rizzo G, Fancellu A and Porcu A: Inflammatory fibroid polyp (Vanek's tumor) of the gastric antrum: Is treatment always mandatory? Ann Ital Chir 87(ePub): S2239253X16024658, 2016. PMID: 26845412.

122 Khadanga S, Dugar D, Khurana U and Satapathy SP: Inflammatory fibroid polyp (Vanek's tumour): My worst nightmare in the Emergency Department. BMJ Case Rep 2016: 2015213688, 2016. PMID: 26873916. DOI: 10.1136/bcr-2015213688

123 Romano-Munive AF, Barreto-Zuniga R, Rumoroso-Garcia JA and Ramos-Martinez P: Inflammatory fibroid polyp of the gastrointestinal tract: 10 Years of experience at the Instituto Nacional de Ciencias Medicas y Nutricion Salvador Zubiran. Rev Gastroenterol Mex 81(3): 134-140, 2016. PMID: 27157712. DOI: $10.1016 /$ j.rgmx.2016.03.001

124 Silva M, Albuquerque A, Cardoso H, Costa J and Macedo G: Gastric inflammatory fibroid polyp mimicking a gastrointestinal stromal tumour. Rev Esp Enferm Dig 108(8): 497-498, 2016. PMID: 27554383.

125 Basara I, Canda AE, Sagol O, Obuz F and Secil M: Intussusception and perforation due to an inflammatory fibroid polyp located in the ileum. Wiener Klin Wochenschr 128(1920): 731-734, 2016. PMID: 27637204. DOI: 10.1007/s00508016-1073-y

126 Aderemi $\mathrm{O}$ and Nicholas A: Rectal inflammatory fibroid polyp in a Nigerian: Case report and brief review of literature. Afr Health Sci 16(3): 873-876, 2016. PMID: 27917224. DOI: 10.4314/ahs.v16i3.31

127 Rodriguez de Santiago E, Zaera de la Fuente C, Penas Garcia B, Gutierrez-Pecharroman AM, Cuno Roldan JL, Arocena Aranguren C, Defarges Pons V, Aguilera Castro L, Boixeda de Miquel D and Albillos Martinez A: Ulcerated submucosal gastric tumor. Could it be a benign condition? Rev Esp Enferm Dig 108(11): 733-735, 2016. PMID: 27822953.

128 Calderon MG, Caivano VC, Bagnaresi S, Jr, de Oliveira Lira JO, Raimundo RD, de Abreu LC and Correa JA: A unique case of inflammatory fibroid polyp in the duodenum of a female adolescent: Case report and literature review. Medicine 96(8): E6131, 2017. PMID: 28225494. DOI: 10.1097/MD.0000000 000006131

129 Shim EJ, Ahn SE, Lee DH, Park SJ and Kim YW: Dynamic enhanced computed tomography imaging findings of an inflammatory fibroid polyp with massive fibrosis in the stomach. World J Gastroenterol 23(11): 2090-2094, 2017. PMID: 28373777. DOI: 10.3748/wjg.v23.i11.2090

130 Zhao Y, Fu YW, Wang WC and Lu T: A Case of inflammatory fibroid polyp with an elongated shape in cecum. Chi Med J 130(17): 2130-2131, 2017. PMID: 28836563. DOI: 10.4103/ 0366-6999.213424

131 Sugawara T, Sugita S, Tateno M, Yabutani A, Segawa K, Ito Y, Tsujiwaki M, Fujita H, Ono $\mathrm{Y}$ and Hasegawa T: Colonic inflammatory fibroid polyp with PDGFRA expression. Pathol Int 68(3): 205-206, 2018. PMID: 29288548. DOI: 10.1111/pin.12625

132 Harima H, Kimura T, Hamabe K, Hisano F, Matsuzaki Y, Sanuki K, Itoh T, Tada K and Sakaida I: Invasive inflammatory fibroid polyp of the stomach: A case report and literature review. BMC Gastroenterol 18(1): 74, 2018. PMID: 29855265. DOI: $10.1186 / \mathrm{s} 12876-018-0808-9$

133 Onisor DM, Boeriu AM, Mocan SL, Bartha JR, Coros MF and Dobru ED: Vanek's tumor: A rare cause of gastric outlet obstruction. Case report and literature review. Rom J Morphol Embryol 59(2): 563-568, 2018. PMID: 30173263.

134 Wronecki J, Błaszkiewicz A, Swatek J and SkrzydłoRadomańska B: Inflammatory fibroid polyp in the antrum cooccurring with adenomatous polyp in the ascending colon. Prz Gastroenterol 13(4): 340-342, 2018. PMID: 30581510. DOI: $10.5114 /$ pg.2018.79816

135 Jan ZU, Muslim M, Ullah K, Shoaib A, Ahmed N, Khan ZM and Aurangzeb M: Vanek's tumor as an unusual cause of ileoileal intessuception - A unique case report Ann Med Surg 32: 14-17, 2018. PMID: 30002823. DOI: 10.1016/j.amsu. 2018.06.006

136 Al Taei TH and Al Mail SA: Small bowel intussusception due to inflammatory fibroid polyp: A case report. Radiol Case Rep 13(4): 801-804, 2018. PMID: 29988929. DOI: 10.1016/ j.radcr.2018.05.008

137 Fleres F, Mazzeo C, Ieni A, Rossitto M and Cucinotta E: Gastric inflammatory fibroid polyp tumor with acute intestinal obstruction-Vanek's tumor can mimick a giant gastrointestinal stromal tumor or a gastric lymphoma. J Vis Surg 4: 54, 2018. PMID: 29682464. DOI: 10.21037/jovs.2018.02.09

138 Kameda C, Miwa H, Kawabata R, Marukawa D, Murakami M, Noura S, Shimizu J and Hasegawa J: Laparoscopic resection of a jejunal inflammatory fibroid polyp that caused occult gastrointestinal bleeding, diagnosed via capsule endoscopy and double-balloon enteroscopy: A Case Report. Clin Endosc 51(4): 384-387, 2018. PMID: 29554795. DOI: 10.5946/ce.2017.162

139 Mantas D, Garmpis N, Polychroni D, Garmpi A, Damaskos C and Kouskos E: Pyloric obstruction caused by inflammatory fibroid polyp: A case report. Case Rep Surg 2019: 8919204, 2019. PMID: 31198616. DOI: 10.1155/2019/8919204

140 Cunningham AS, Siddique AS, Ligato S and Vignati PV: A large inflammatory fibroid polyp of the rectum removed by transanal excision. J Surg Case Rep 2019(6): rjs164, 2019 PMID: 31191902. DOI: $10.1093 /$ jscr/rjz164

141 Oka K, Inoue K, Iwai N, Hara T, Inada Y, Tsuji T, Komiyama S, Okuda T, Sai S, Nagata A, Komaki T, Naito Y, Itoh Y and Kagawa K: Laparoscopy endoscopy cooperative surgery for inflammatory fibroid polyp in the esophagus. Intern Med 58(16): 2357-2362, 2019. PMID: 31118386. DOI: 10.2169/ internalmedicine.2595-18

142 Watahiki Y, Hikichi T, Watanabe K, Nakamura J, Kikuchi H, Hahimoto M, Takagi T, Suzuki R, Sugimoto M, Konno N, Sato Y, Irie $\mathrm{H}$ and Ohira $\mathrm{H}$ : A case of inflammatory fibroid polyp of the stomach with an "erect penis like appearance" successfully removed by endoscopic submucosal dissection. Clin J Gastroenterol 12(3): 279-284, 2019. PMID: 30684138. DOI: 10.1007/s12328-019-00935-5

143 Wang H, Zhou T, Zhang C, Li H and Lü M: Inflammatory fibroid polyp: an unusual cause of abdominal pain in the upper gastrointestinal tract: A case report. Open Med 15: 225-230, 2020. PMID: 32258417. DOI: 10.1515/med-2020-0033

144 Karuhanga T, Ngimba C and Yahaya JJ: Inflammatory fibroid polyp in a 48-year-old male: A rare cause of intussusception Case Rep Surg 2020: 9251042, 2020. PMID: 31970009. DOI: $10.1155 / 2020 / 9251042$

145 Park KB, Jeeb YS and Kimb D-W: Laparoscopic resection of two inflammatory fibroid polyps: An unusual cause of jejunojejunal intussusception. Int J Surg Case Rep 69: 20-23, 2020. PMID: 32248011. DOI: 10.1016/j.ijscr.2020.03.029 
146 Stolte M, Sticht T, Eidt S, Ebert D and Finkenzeller G: Frequency, location, and age and sex distribution of various types of gastric polyp. Endoscopy 26(8): 659-665, 1994. PMID: 7859674. DOI: $10.1055 / \mathrm{s}-2007-1009061$

147 Wysocki AP, Taylor G and Windsor JA: Inflammatory fibroid polyps of the duodenum: A review of the literature. Dig Surg 24(3): 162-168, 2007. PMID: 17476106. DOI: 10.1159/000102099

$148 \mathrm{Kim}$ YI and Kim WH: Inflammatory fibroid polyps of gastrointestinal tract. Evolution of histologic patterns. Am J Clin Pathol 89(6): 721-727, 1988. PMID: 3369362. DOI: 10.1093/ajcp/89.6.721
149 Pantanowitz L, Antonioli DA, Pinkus GS, Shahsafaei A and Odze RD: Inflammatory fibroid polyps of the gastrointestinal tract: Evidence for a dendritic cell origin. Am J Surg Pathol 28(1): 107-114, 2004. PMID: 14707872.

150 Wille P and Borchard F: Fibroid polyps of intestinal tract are inflammatory-reactive proliferations of CD34-positive perivascular cells. Histopathology 32(6): 498-502, 1998. PMID: 9675587.

Received September 1, 2020

Revised October 4, 2020

Accepted October 6, 2020 